Summer 8-6-2021

\title{
Reduction of CLABSI in Telemetry Patients through Limiting Central Line Blood Draw
}

\section{Caselyn Lok}

University of St. Augustine for Health Sciences, c.lok@usa.edu

DOI: https://doi.org/10.46409/sr.NVV01806

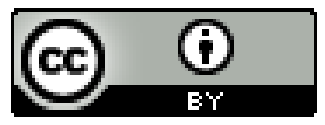

This work is licensed under a Creative Commons Attribution 4.0 License.

Follow this and additional works at: https://soar.usa.edu/scholprojects

Part of the Critical Care Nursing Commons, Family Practice Nursing Commons, and the Other Nursing Commons

\section{Recommended Citation}

Lok, C. (2021). Reduction of CLABSI in Telemetry Patients through Limiting Central Line Blood Draw. [Doctoral project, University of St Augustine for Health Sciences]. SOAR @ USA: Student Scholarly Projects Collection. https://doi.org/10.46409/sr.NVV01806

This Scholarly Project is brought to you for free and open access by the Student Research at SOAR @ USA. It has been accepted for inclusion in Student Scholarly Projects by an authorized administrator of SOAR @ USA. For more information, please contact soar@usa.edu, erobinson@usa.edu. 
Reduction of CLABSI in Telemetry patients through limiting central line blood draw Caselyn Lok, BSN, RN

School of Nursing, University of St. Augustine for Health Sciences

This Manuscript Partially Fulfills the Requirements for the Doctor of Nursing Practice Program and is Approved by:

Robin Kirschner, EdD, DNP, RN, NEA-BC, CNL, CNE

Rendi Solis, DHA, MSN, BSN, RN, NEA-BC, CLSSGB, FACHE

August 6, 2021 


\begin{abstract}
CLABSI is known to be one of the many healthcare-associated infections that has led to an increase in health complications, length of hospital stays, and increased in healthcare cost. There is about 25000 bloodstream infection that occurs annually (Haddadin, Annamaraju, \& Regunath, 2020). The PICOT question that guided this project was "How does limiting blood-draw from central venous catheter lines influence the rate of central-line associated bloodstream infections (CLABSI) post-implementation compared to rate of CLABSI pre-implementation after eight weeks?" CLABSI prevention bundles were already being used to guide healthcare providers in handling CVC access. There were 15 scholarly articles that supports the use of bundle programs in CVC access and addressing CLABSI. The reduction in handling and manipulation of the CVC access leads to lesser risks of infection. The intervention in this project is the reduction of the CVC access through the limiting of blood draws from central lines with rare exceptions. CVC is primarily used only for the administration of intravenous fluids, antibiotic, parenteral nutrition, and blood products. The intervention utilized a structured decision-making framework to follow during blood draws to avoid using the central line. The project resulted to a reduction of CLABSI rate from $7.9 \%$ pre-implementation rate to $0 \%$ post-implementation. The limiting of CVC access led to reduced CLABSI episode in the telemetry unit compared to the national average of 5.94\%. The project has proven how the intervention implemented can be used in CLABSI prevention bundles to address healthcare associated infections.
\end{abstract}

Keywords: limiting central line access, infection reduction, central line catheter care,

\title{
CLABSI
}




\section{Reduction of CLABSI in Telemetry patients through limiting central line blood draw}

There are about thousands of deaths and billions of healthcare costs associated with central line-associated bloodstream infection (CLABSI) annually (Centers for Disease Control and Prevention [CDC], n.d.). CLABSI is a form of hospital-acquired infection that affects patients in the hospital that have an inserted central venous catheter (CVC). CDC reports about 30,100 CLABSI occurs in the United States annually resulting in deaths and an increase in healthcare costs (Williamson, Gonzales, Neusbaum, \& Messing, 2017). The goal of the project was to reduce the CLABSI rate through the limiting of CVC blood draws. The CVC was used solely to administer medication and treatments to the patient with only rare exceptions.

\section{Significance of the Practice Problem}

Healthcare-associated infections (HAI) are challenges that many healthcare organizations face. According to the CDC (2015), about 1 in 31 patients in the United States acquire at least one HAI each day. Based on the 2015 National and State HAI Progress Report, about 72000 patients died with HAI in the hospital during their stay (CDC, 2020). One of the many HAIs seen in acute care facilities is CLABSI together with catheter-associated urinary tract infections, ventilator-associated events, surgical site infections, methicillin-resistant Staphylococcus aureus bloodstream events, and Clostridium difficile. There is about 25000 bloodstream infection that occurs annually (Haddadin, Annamaraju, \& Regunath, 2020).

A study by Stevens et al. (2013), observed that there are higher hospital costs and risk of in-hospital mortality with patients that have CLABSI. Patients that have CLABSI are associated with $\$ 33,000$ excess variable cost during their hospital stay (Stevens et al., 2013). According to the CDC (2015), CLABSI significantly increases hospital length of stay and causes a mortality rate of about $12-25 \%$. The United States government passed several legislations that greatly 
affected the evolution of value-based programs such as the Affordable Care Act (ACA) in 2010 that addresses HAI prevention programs. The ACA required healthcare organizations to lower the HAI rate, such as CLABSI rates, to avoid a $1 \%$ Medicare reimbursement reduction (CMS, 2020). About $\$ 96$ is deducted from a $\$ 9600$ reimbursement due to the hospital-acquired condition reduction program (CMS, 2020).

Efforts to reduce CLABSI is initiated by healthcare organizations to help curb healthcare cost and avoid financial penalties (Woodward, \& Umberger, 2016). If CLABSI is addressed properly, a large portion of this cost savings may be re-allotted to other important aspects of healthcare such as better resource allocation, updates in infrastructure, and purchases of equipment. The healthcare organization has been tracking down their hospital-acquired infections and have noticed how CLABSI is prevalent in their telemetry units. Various interventions are already in place to help reduce CLABSI in the telemetry unit but is still deemed ineffective.

\section{PICOT Question}

The PICOT question guiding this project is, in Telemetry patients, how does limiting blood-draw from central venous catheter lines influence the rate of central-line associated bloodstream infections (CLABSI) post-implementation compared to rate of CLABSI preimplementation after eight weeks?

The project was implemented in the adult Telemetry Unit. The intervention was to limit the current practice of regularly drawing blood from CVC. There were limited blood draws from CVC for eight weeks with rare exceptions. The project compared the CLABSI rates before and after the implementation of the project. 
Evidence-Based Practice Framework \& Change Theory The project was

guided by the Johns Hopkins evidence-based practice (JHEBP) framework (White, Dudley-

Brown, \& Terhaar, 2016). JHEBP assures the highest quality of care through the implementation of practices that are useful through research and project implementation (White et al., 2016).

The model includes three professional domains that include nursing practice, education, and research. The project was supported by previous investigations conducted that shows how limiting blood draws from CVC reduced CLABSI rates. The nursing staff was educated on how to adapt the intervention into their nursing practice through following a CVC blood draw process. The process was reflected and guided through a decision-making framework created by the project manager. The nurses were trained on how to limit the use of CVC for blood draws as much as possible and only to perform it during rare exceptions.

The JHEBP framework has three phases: practice question, evidence, and translation (White et al., 2016). In this project, the practice question is how the limiting of CVC blood draw affects the reduction of CLABSI rate among Telemetry patients compared to pre-intervention CLABSI rate? The evidence results from previous research and literature demonstrates how limiting CVC blood draw reduces the rates of CLABSI in different healthcare settings (Williamson et al., 2017; Kuriakose, 2020). The significant effect of limiting CVC blood draws on CLABSI drove the healthcare organization to adapt the same evidence-based practice into their CVC care. In the healthcare organization, knowledge translation was the process of planning, implementing, evaluating, and communicating the adaptation of the practice of limiting CVC blood draws in their Telemetry unit. The results of the study were shared with the staff to implicate the effectiveness of the project in reducing CLABSI to promote compliance with the new intervention. 
The change theory that served as a foundation of this project was Kurt Lewin's change

theory (White et al., 2016). This change theory involved three processes which were unfreezing, change, and refreezing (White et al., 2016). The unfreezing phase was the identification of the problem within the organization. Important health issues were discussed, and improvement opportunities were acknowledged. In this project, the unfreezing phase was the review of the hospital's practices in handling CVC. The implication of limiting CVC blood-draw was reviewed through the comparison of CLABSI rates before and after the project implementation. The change phase was the actual implementation of the intervention within the Telemetry unit. After eight weeks, the effects of the project implementation were evaluated and discussed with the stakeholders. The refreezing phase was where the positive effect of the limiting of CVC blood draw in reducing the CLABSI rate was recognized, and the practice was adapted in other units of the organization.

\section{Evidence Search Strategy}

To discuss the effectiveness of limiting CVC blood draws in the reduction of CLABSI, several literature searches were conducted. The literature review was performed by searching for publications done within the last ten years. Studies were published from the years 2010 to 2020 . Multiple databases were used such as the University of Saint Augustine library, PubMed, PubMed Health, CINAHL, and Google Scholar. The following keywords were used as search terms: limiting central line access, infection reduction, central line catheter care, and CLABSI. There was a total of 338 publications that initially resulted by the search. The Prisma diagram was followed to narrow down the selection. Duplicates were removed and articles were analyzed to check if they were aligned with the project topic. A total of 22 articles were left after the screening process. Articles that have a pediatric population or any population less than 18 years old were excluded. There was a total of 15 publications used to support the project. 


\section{Evidence Search Results}

A literature review serves as a good foundation for developing the purpose and validity of the project. Numerous studies and articles were published throughout the years since healthcare is ever-changing. The literature review was screened for eligible publications as reflected in the PRISMA Diagram (see Appendix A).

The evidence search resulted in 338 articles. The initial evidence was from the 218 results from the Google Scholar database and 120 from other database search engines such as PubMed, CINAHL, and the University of St. Augustine Library. Duplicate results were eliminated, and the search was narrowed down to 69 publications. These records were reviewed by the author and narrowed down again to 22 publications. After another assessment by the author, there were a total of 15 publications left that was used in the project.

The Johns Hopkins Nursing Evidence-Based Practice quality guide was used to identify the level, quality, and quantity of the literature gathered. Based on the 15 final articles, there were 2 systematic reviews and 13 primary research evidence (see Appendix B \& C). The primary research evidence has five Level I articles, two Level III articles, two Level IV articles, and six Level V articles (see Appendix D). There were two systematic reviews that both have high quality (see Appendix E).

\section{Themes with Practice Recommendations}

Upon review of the literature, certain practice principles and recommendations were identified. Practice recommendations in reducing CLABSI rate was based on the significance of the intervention to the organization, population of the study, interprofessional collaboration, intervention bundles, and limitation of CVC access. 


\section{Impact of CLABSI reduction}

A HAI has been one of the major concerns that are continuously developing in healthcare. CMS has launched multiple efforts to address this issue through the implementation of pay-for-performance reimbursement measures. Healthcare organizations that perform based on a standard infection rate accept better reimbursement and avoid monetary penalties. Based on the literature collated, about $50 \%$ of the studies are focused on reducing CLABSI to reduce readmission, mortality, and morbidity. Haddadin et al. (2020) also support the importance of evidence-based medicine in the improvement of CLABSI reduction practices to address prolonged hospital stays and increased healthcare costs.

In an attempt to nationally reduce the CLABSI rate, in 2003, healthcare organizations were mandated to report CLABSI and other HAI regularly to the National Healthcare Safety Network (NHSN) (Woodward, \& Umberger, 2016). The mandatory reporting pressures healthcare organization to keep its rate below the national average. Boyce et al. (2013) also discussed the effect of the need to report CLABSI rates to the NHSN timely.

\section{Population}

CLABSI rates are widely seen in the acute care setting as evidenced by eight of the 15 works of literature. CVC is mostly used in critically ill patients to provide faster care such as medication and nutritional administration (Bell, \& O'Grady, 2017; Haddadin et al., 2020).

\section{Interprofessional Collaboration}

Efforts to reduce CLABSI were created by multifaceted professionals to provide the best intervention recommendations to be used in the telemetry unit. Healthcare professionals were also educated and trained to properly implement interventions to reduce the CLABSI rate. Any initiative is always partnered with information-sharing to promote compliance and success of the project (Devries, 2019). Members of the interdisciplinary team such as patients, nurses, 
physicians, and phlebotomists were given information and educated to understand the importance of CLABSI reduction and how it affects their roles (Blot, Bergs, Vogelaers, Blot, \& Vandijck, 2014; Williamson et al., 2017). Consequences such as severe infection, mortality, morbidity, hospital readmission rate, and healthcare cost were discussed and reviewed in almost half of the studies to stress out the importance of CLABSI rate reduction. It is important to promote professional accountability in following CLABSI guidelines to see better infection rate reduction results (Devries, 2019).

\section{CLABSI bundles}

Reviews of the related literature have created a list of interventions that best address CLABSI. These proactive interventions were utilized solely or as a bundle based on the organization's policy and protocols. Seven studies have recommended following hand hygiene, aseptic technique during placement or insertion of CVCs, site selection, review of the indication of a catheter for possible removal, appropriate dressing change, injection hub or port disinfection, and limiting blood draws.

CLABSI bundles have been around since 2003 when the initiative to reduce HAI was started (Woodward, \& Umberger, 2016). Based on the review, almost all healthcare institution has been following protocols on good hygiene, disinfection of sites, and review for continued use. But not all are practicing the limiting of access to CVCs as the main protocol to follow in CLABSI reduction. There was a significant agreement within the literature that it is highly recommended to bundle blood tests together in one draw to limit peripheral and CVC draw (Kuriakose, 2020; Valencia, et al., 2016; Williamson et al., 2017).

\section{Limiting CVC access}

Five studies supported that limiting exposure or manipulation of CVCs significantly reduced CLABSI rates (Boyce et al., 2013; Kuriakose, 2020; Truini-Pittman, Sullivan, Pedersen, 
REDUCTION OF CLABSI IN TELEMETRY PATIENTS

Mistry, \& Williams, 2015; Valencia, et al., 2016; Williamson et al., 2017). CLABSI rates were closely linked with practices in handling and maintaining central lines (Valencia et al., 2016). Completely restricting blood draw from CVC was challenging. Most patients were given the reason for $\mathrm{CVC}$ insertion as a means of reducing punctures for peripheral blood draws (TruiniPittman et al., 2015). In a study by Williamson et al. (2017), instead of restricting CVC blood draws they curtailed to limiting them. The study made exceptions such as blood draws during codes or critically ill patients, stat blood samples, and blood culture before starting antibiotics. To limit access blood tests were screened and recommended to be drawn together to limit CVC access (Williamson et al., 2017). Nurses and nurse leaders played an important role in performing the screening of the blood test orders to reduce blood draws peripherally and limit CVC use. It is important to create an institutional policy or guideline to minimize the manipulation of CVCs to reduce infection rates (Boyce et al., 2013).

\section{Setting, Stakeholders, and Systems Change}

The project was implemented at a 400-bed acute care hospital in Southern California. It expanded throughout the years and is currently providing multidisciplinary care through various healthcare units. One of the many initiatives of the organization to promote health within their patients is to reduce the rate of HAI. The stakeholders mainly the Chief Nursing Officer, Quality Improvement Officer, and Patient Safety Officer has been evaluating the organization's quality metrics to identify areas of opportunities to improve care. HAI specifically CLABSI has been a challenge in the organization particularly their telemetry units because it is currently the unit that has most of the CLABSI occurrence. The participants were patients in the adult telemetry unit that have CVC. The stakeholders and project implementor met with the telemetry director, managers, and lead nurses in discussing practice change through adaptation of evidence-based interventions in reducing CLABSI rates. The practice of limiting central line blood draws have 
been initiated and widely used in other states but not yet in California. The project was decided to be beneficial, and the impact of the implementation was greatly anticipated to improve quality measures within the organization.

The project was a meso-level change because it affected the specific unit of the hospital. It promoted an adaptation of the EBP to address CLABSI within the telemetry unit. The success of the project was guided through interprofessional collaboration within the unit it was implemented. The CNO, director of telemetry, and medical director of the telemetry unit discussed the positive impact of the project. The project of limiting CVC blood draws greatly relied on the understanding of the healthcare professionals about the benefits of the project. It required the skill and knowledge of the nurses to screen unnecessary blood draw orders and to recommend the limiting of CVC blood draw because it is essential in the reduction of CVC manipulation. The interprofessional team were also mindful of bundling blood draw test to reduce peripheral pricks and to only use CVC during rare exceptions.

A SWOT analysis is a tool that identifies the internal and external environment and strategic focus for an organization. This analysis can help an organization synthesize data and trends into specific issues that can be incorporated into a project plan (Walston, 2018). The components include the identification of strengths, weakness, threats, and opportunities.

A SWOT analysis was conducted to assess the anticipated success of the project (see Table 3 in Appendix F). The strength of the project was the support of the stakeholders and healthcare leaders in the organization. Open communication between the leaders and the employees permitted better implementation of the project. The weakness of the project was the limitation in sample size because it was only done in the telemetry unit. Patient census and number of CVC insertions vary. The screening of blood draws and recommendations to limit CVC draws became an oversight. An evident opportunity of the project was the positive impact 
it brought to the quality measure of the organization. It also opened the discussion of updates on policies based on changes in healthcare practice. Threats were the inconsistencies with the census in the telemetry unit and the staffing shortage due to the COVID-19 pandemic. The short staffing and increase staff turnover affected the screening and limiting process of the CVC blood draws.

\section{Implementation Plan with Timeline and Budget}

The project identified how limiting CVC blood draws affected the CLABSI rate in the telemetry unit within eight weeks of implementation. The nurses followed the updated CVC blood draw process with instructions (see Appendix G). The nurses were able to use it as a guide to screen blood draw orders and identify opportunities to perform bundle blood draws to reduce CVC access manipulation. The physician's working in the telemetry unit were able to follow the protocol of limiting unnecessary CVC blood draw orders.

According to Larrat, Marcoux, and Vogenberg (2012), it is imperative that health care professionals are aware of the regulations the government is creating. These government regulations will greatly affect the decision-making within health care organizations and how roles of practitioners might change ultimately affecting the quality of care being rendered to patients (Larrat, Marcoux, \& Vogenberg, 2012). For this project, the new process of limiting

CVC blood draw was a response to the national and local drive to address CLABSI rate.

Interprofessional collaboration was essential in promoting the success of the project. The quality-of-care development and organization change was necessary for the healthcare organization to thrive and meet the ever-changing needs of its clients. To promote a successful project, effective leadership is necessary. According to Carucci (2016), an organization will only be able to reach excellence or their goal when the leader starts the transformation from within. It 
was important to discuss the impact of CLABSI as an avoidable event in the organization through educating the staff. The change and improvement must start within the leader first to prepare followers. In this project, the telemetry director and telemetry managers reviewed and discussed the new blood draw process and its positive impact on the unit's performance measures. The information was relayed to the telemetry nurses through education and training. There were education sessions weekly during the project implementation explaining the new CVC blood draw process. A regular reminder of the intervention was included in each shift's huddle. This allowed better education of staff nurses and encouragement of project compliance. Peripheral draws were the preferred method unless deemed urgent or as specified in the blood draw process diagram (see Appendix G). The CVC blood draw process diagram were posted in strategic locations within the telemetry unit to remind the staff of the process. The project manager was not physically present in the project location every day that is why the nurse leaders played a key role in ensuring that the implementation process was done correctly and consistently.

After the education of the whole unit's nursing team, the project was initiated for eight weeks. Rare cases of exception were identified as CVC blood draws due to physician orders, emergent draw during codes or life-threatening events, poor veins of the patient, patient refusal of peripheral draws, and nurses' forgetting the new process. The cases of rare exceptions were logged by the nurse in the CVC blood draw log (see Appendix H). Data on CVC presence and CLABSI occurrence was collected weekly and was recorded in the CVC tracking log (see Appendix I). This log was used to compute CLABSI rates. The data ultimately was tabulated at the end of eight weeks and analyzed compared to the organization's pre-project implementation, federal, and state averages. The data post-project implementation was compared to data preproject implementation to evaluate the effect of the project in the organization. The analysis 
was reviewed and presented by the project manager to the stakeholders. A detailed discussion of the project schedule was visually represented in a Gantt Chart (see Appendix J).

The project had a limited budget because there was no additional resource necessary to implement it (see Appendix K). The project was focused on limiting the ordering of CVC blood draws if it is nonemergent and to bundle blood draw orders together. The budget allotted was used in the education and training process of the nurses, physicians, and other members of the telemetry interprofessional team.

\section{Results}

In order to initiate the project, a review of the project proposal was done by the University of St Augustine for Health Sciences’ Evidence-Based Practice Review Council. Upon approval, the whole project proposal was sent to the stakeholder of the institution (see Appendix M). The institution's Internal Review Board reviewed the proposal to ensure the promotion of patient safety and confidentiality. The project was approved by the Chief Nursing Officer (see Appendix N).

The selection of the participants was done using inclusion and exclusion criteria. Patients admitted to the telemetry unit that have a CVC qualified as a participant. Patients with central line access are considered a participant regardless of the insertion site. Various data were also collected to identify how effective the limitation of CVC blood draws in reducing CLABSI rates. The number of central venous catheter days and episodes of CLABSI was tabulated each month using the $\mathrm{CVC}$ tracking $\log ($ Appendix $\mathrm{H})$ to get numbers to compute the CLABSI rates. The data was collected through the review of the patient's medical chart using the organization's EMR. The organization's infection preventionist collects and stores the data within the organization's information cloud. This way the data was securely stored. The project manager was given on-site access to data during the whole duration of the project. The patient 
REDUCTION OF CLABSI IN TELEMETRY PATIENTS

information was protected using HIPAA guidelines. The data collected was screened and tabulated excluding the name of the patient. Only the location of the central line, device days, and presence of CLABSI was tabulated in the Central Venous Catheter Tracking Log (see Appendix I).

NHSN creates a baseline rate of infections related to aggregated data reported by healthcare facilities around the United States (CDC, 2015). The National and State HAI Progress Report on CLABSI sets the average infection rate at 5.94\%. During the project the CLABSI rate was computed and analyzed together by the infection preventionist and project manager. The CLABSI rate was logged in the CLABSI Rate Computation Table (Appendix O). The CLABSI rate was computed monthly, and the rate was collected to reflect eight weeks of pre-implementation and post-project implementation. The NHSN created a standardized formula to compute the CLABSI rate and will validate the integrity of the data analysis in this project. CLABSI rate is calculated per 1,000 central-line days by dividing the number of CLABSI episodes by the number of actual central-line days and multiplying the result by 1,000 (see Appendix L).

In the pre-implementation phase, it was found that there was one CLABSI identified among 126 device days in January 2021. The CLABSI infection rate was $7.9 \%$ which is above the national infection rate average. The goal of the project was to reduce the CLABSI rate below the national average through the limiting of CVC blood draws. The project was found effective during the post-project implementation because the CLABSI rate is lower than the preimplementation CLABSI rate. The CLABSI rate for May is $13 \%$ due to one CLABSI episode. The patient was admitted after the project implementation and was excluded from the final data tabulation of these project. Ultimately, there were no CLABSI during the eight-week 
REDUCTION OF CLABSI IN TELEMETRY PATIENTS

project implementation during selected days in March, April, and May reflecting an infection rate of $0 \%$

(see Appendix O).

A two-tailed independent samples t-test was conducted as the statistical procedure to examine whether the results of the intervention between the pre-project implementation and postproject implementation have a significant change.

\section{Assumptions}

Levene's test was conducted to assess whether the variance of the numbers of infections was equal between the pre-project implementation and post-project implementation group. The result of Levene's test for the number of infections was not significant based on an alpha value of $0.05, F(1,103)=2.21, p=.140$. This result suggests it is possible that the variance of the number of infections is equal for each pre-project implementation and post-project implementation group, indicating the assumption of homogeneity of variance was met.

\section{Statistical Results}

The result of the two-tailed independent samples $t$-test was not significant based on an alpha value of $0.05, t(103)=1.49, p=.140$, indicating the null hypothesis cannot be rejected. This finding suggests the mean of the numbers of infections was not significantly different between the pre-project implementation and post-project implementation group. The results are presented in Table 1. A bar plot of the means is presented in Figure 1.

Table 1 Two-Tailed Independent Samples t-Test for Number of Infection by implementation group

\begin{tabular}{|c|c|c|c|c|c|c|c|}
\hline \multirow[b]{2}{*}{ Variable } & \multicolumn{2}{|c|}{ Pre-Project } & \multicolumn{2}{|c|}{ Post Project } & \multirow[b]{2}{*}{$t$} & \multirow[b]{2}{*}{$p$} & \multirow[b]{2}{*}{$d$} \\
\hline & $M$ & $S D$ & $M$ & $S D$ & & & \\
\hline
\end{tabular}


Number of Infections

0.03

0.17

0.00

0.00

1.49

.140

0.25

Note. $\mathrm{N}=105$. Degrees of Freedom for the $t$-statistic $=103 . d$ represents Cohen's $d$.

Figure 1 The mean of the number of infections by levels of project implementation group

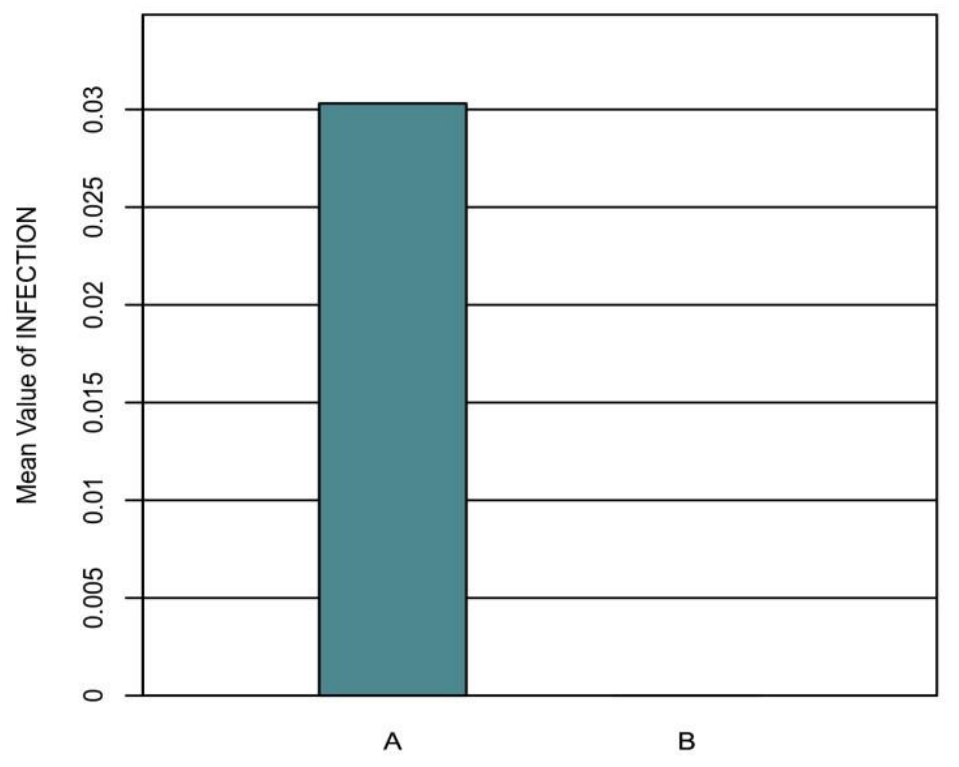

Pre-implementationgRBost Implementation

\section{Impact}

The project's goal was to reduce the CLABSI rate in the telemetry unit. The limitation of blood draw from central lines reduced the possible bacterial introduction to the ports every time it is being accessed. Thus, reducing the risks for the formation of infection. The project educated and empowered the nursing staff to be mindful of how they use and care of the central lines. The outcome of the project reduced the CLABSI infection rate from $7.9 \%$ to $0 \%$. Before the project implementation, the nurses were automatically given supplies by the phlebotomists to collect blood directly from the central lines. Since the implementation, both professions had worked on a process of performing peripheral blood draws first prior to resulting to central line draws during rare cases such as patient refusal and hardsticks. The positive effect of the project had led to a systemic change in the institution. It was decided that there will be no central line 
blood draws in the entirety of the institution, only during rare exceptions as discussed earlier.

This leap will surely promote the reduction of CLABSI in other department of the institution and improve the quality of care provided to the patients.

It such a great change in the system that its sustainability is promoted through ongoing education and training of the staff. The daily review of central line implications has helped in promoting best practices in infection control geared towards reducing CLABSI in the whole institution. The continues review of stakeholders such as the nursing leaders, infection preventionists, and director of quality management will ensure ongoing effectiveness of the project.

\section{Dissemination}

The result of the project was shared with the main stakeholders of the organization that is composed of the Chief Nursing Officer, Director of Quality, Infection Preventionist, and Patient Safety Officer. Clinical leaders such as directors and managers of various departments was invited. The result was presented through a meeting in the organization's conference room.

The goal was to share information that will benefit the community. The project was shared with the local community within the organization's county of location through its public health. A copy of the project was shared to the Orange County Public Health office. The result of the project is shared with other healthcare professionals by making it available through the archives at the University of St. Augustine for Health Sciences Scholarship and Open Access Repository.

\section{Conclusion}

Interprofessional collaboration was essential in attaining success during the project. The healthcare team worked together to improve the screening process in reviewing CVC blood draw orders to identify if it is necessary or can be limited. A better understanding of the project 
REDUCTION OF CLABSI IN TELEMETRY PATIENTS

process and implication provided better adherence to the project implementation. The reduction

of automatic $\mathrm{CVC}$ blood draw order and the promotion of bundled peripheral blood draws led to reduced manipulation of the central line. The goal of the project to implement an evidence-based practice that will reduce CLABSI rates was met. The regulation of the access and manipulation of CVC reduced the risk for contamination of central lines. The limiting of CVC blood draw reduced the CLABSI rate in the telemetry unit from $7.9 \%$ to $0 \%$. This project suggests that the use of limiting CVC blood draw is an effective intervention that should be included in CLABSI bundles to have better results in addressing HAI.

\section{References}

Bell, T., \& O'Grady, N. P. (2017). Prevention of central line-associated bloodstream infections. Infectious disease clinics of North America, 31(3), 551-559. https://doi.org/10.1016/j.idc.2017.05.007

Blot, K., Bergs, J., Vogelaers, D., Blot, S., \& Vandijck, D. (2014). Prevention of central lineassociated bloodstream infections through quality improvement interventions: A systematic review and meta-analysis. Clinical Infectious Diseases, 59(1), 96-105. https://doi.org/10.1093/cid/ciu239

Boyce, J. M., Nadeau, J., Dumigan, D., Miller, D., Dubowsky, C., Reilly, L., \& Hannon, C. V. (2013). Obtaining blood cultures by venipuncture versus from central lines: impact on blood culture contamination rates and potential effect on central line-associated bloodstream infection reporting. Infection control and hospital epidemiology, 34(10), 1042-1047. https://doi.org/10.1086/673142 
Carucci, R. (2016). Organizations can't change if leaders can't change with them.

Harvard Business Review. Accessed from

https://hbr.org/2016/10/organizations-cant-change-if-leaders-cant-change-

withthem?utm_source=twitter\&utm_medium=social\&utm_campaign=harvard

biz

Centers for Disease Control and Prevention. (n.d.). Central line-associated bloodstream infection

(CLABSI). Retrieved from https://www.cdc.gov/hai/bsi/bsi.html

Centers for Disease Control and Prevention. (2015). Preventing healthcare associated infections.

Retrieved from https://www.cdc.gov/HAI/prevent/prevention.html\#hhs

Centers for Disease Control and Prevention. (2020). Current HAI progress report.

Retrieved from https://www.cdc.gov/hai/data/portal/progress-report.html

Centers for Medicare and Medicaid Services. (n.d.). What are value-based programs?

Retrieved from https://www.cms.gov/Medicare/Quality-Initiatives-Patient-Assessment-

Instruments/Value-Based-Programs/Value-Based-Programs.html

Centers for Medicare and Medicaid Services. (2020). Quality measures.

Retrieved from https://www.cms.gov/Medicare/Quality-Initiatives-Patient-AssessmentInstruments/QualityMeasures

DeVries, M. (2019). Revisiting CLABSI prevention strategies: Part 2. American Nurse. https://www.myamericannurse.com/revisiting-clabsi-prevention-strategies-part-2/

Frisnia, M. (2014). Self-awareness: The basic competency of the influential leader.

From influential leadership: change your organization, change health care. Health Administration Press, 17-37.

Haddadin, Y., Annamaraju, P., \& Regunath, H. (2020). Central line associated blood stream infections (CLABSI). In: StatPearls [Internet]. 
REDUCTION OF CLABSI IN TELEMETRY PATIENTS

https://www.ncbi.nlm.nih.gov/books/NBK430891/\#

Intellectus Statistics [Online computer software]. (2021). Intellectus Statistics.

https://analyze.intellectusstatistics.com/

Kuriakose, L. (2020). Decreasing central line associated bloodstream infection through limiting the use of central venous catheters for routine blood draws. Journal of Doctoral Nursing Practice, 3(2),173-183. doi: 10.1891/JDNP-D-19-00071.

Larrat, P., Marcoux, R., \& Vogenberg, R. (2012). Impact of federal and state legal trends on health care services. Pharmacy and Therapeutics, 37(4), 218-220, 224-226.

Ling, M. L., Apisarnthanarak, A., Jaggi, N., Harrington, G., Morikane, K., Thu, 1., Ching, P., Villanueva, V., Zong, Z., Jeong, J. S., \& Lee, C. M. (2016). APSIC guide for prevention of Central Line Associated Bloodstream Infections (CLABSI). Antimicrobial resistance and infection control, 5, 16. https://doi.org/10.1186/s13756-016-0116-5

Page, J., Tremblay, M., Nicholas, C., \& James, T. A. (2016). Reducing oncology unit central line-associated bloodstream infections: Initial results of a simulation-based educational intervention. Journal of Oncology Practice, 12(1), e83-e87. https://doi.org/10.1200/JOP.2015.005751

Stevens, V., Geiger, K., Concannon, C., Nelson, R., Brown, J., \& Dumyati, G. (2013). Inpatient costs, mortality and 30-day re-admission in patients with central-line-associated bloodstream infections. Clinical Microbiology and Infection, 20, 0318-0324. doi: 10.1111/1469-0691.12407.

Truini-Pittman, L., Sullivan, L., Pedersen, K., Mistry, T., \& Williams, J. (2015). Reducing central line-associated bloodstream infections. Oncology Nursing News. http://www.oncnursingnews.com/publications/oncology-nurse/2015/may2015/reducingcentrallineassociated-bloodstream-infections 
Valencia, C., Hammami, N., Agodi, A. et al. (2016). Poor adherence to guidelines for preventing central line-associated bloodstream infections (CLABSI): results of a worldwide survey. Antimicrobial Resistance Infection Control, 5(49). https://doi.org/10.1186/s13756-016-0139-y

White, K. M., Dudley-Brown, S. \& Terhaar, M. F. (2016). Translation of evidence into nursing and health care (2nd ed.). New York, NY: Springer Publishing Company.

Williamson, K., Gonzales, L., Neusbaum, A., \& Messing, J. (2017). Reducing the risk of central line-associated bloodstream infections. American Nurse Today, 12(5).

https://www.myamericannurse.com/reducing-risk-central-line-associatedbloodstreaminfections/

Woodward, B., \& Umberger, R. (2016). Review of best practices for CLABSI prevention and the impact of recent legislation on CLABSI reporting. SAGE Open, 1-7. https://journals.sagepub.com/doi/10.1177/2158244016677747 


\section{Figure 1}

PRISMA Diagram

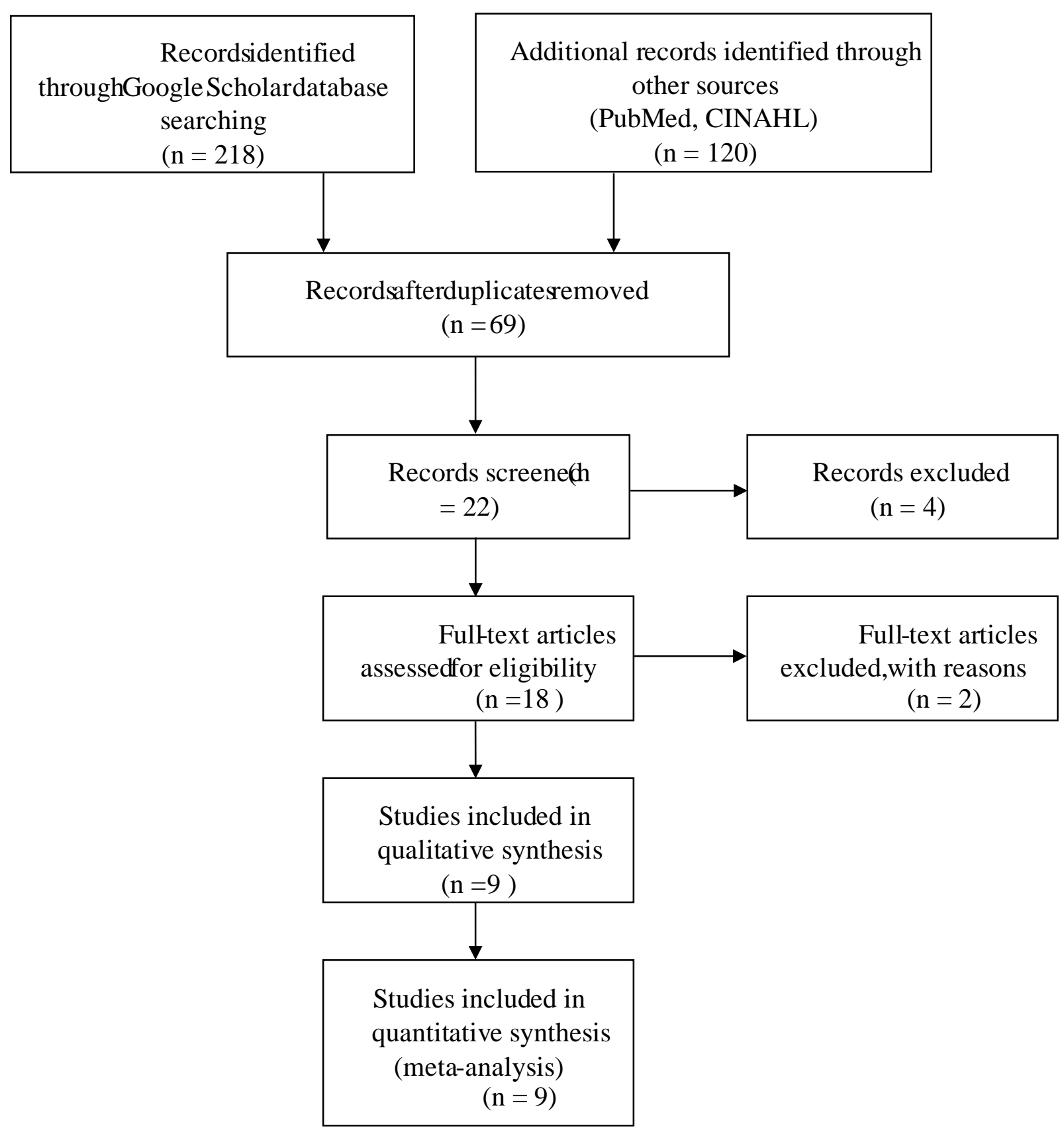




\section{Appendix B}

\section{Table 2}

Summary of Primary Research Evidence

\begin{tabular}{|c|c|c|c|c|c|c|}
\hline Citation & $\begin{array}{l}\text { Design, Level } \\
\text { Quality Grade }\end{array}$ & $\begin{array}{c}\text { Sample } \\
\text { Sample size }\end{array}$ & $\begin{array}{c}\text { Intervention } \\
\text { Comparison } \\
\text { (Definitions } \\
\text { should include } \\
\text { any specific } \\
\text { research tools } \\
\text { used along with } \\
\text { reliability \& } \\
\text { validity) }\end{array}$ & $\begin{array}{l}\text { Theoretical } \\
\text { Foundation }\end{array}$ & $\begin{array}{l}\text { Outcome } \\
\text { Definition }\end{array}$ & $\begin{array}{c}\text { Usefulness } \\
\text { Results } \\
\text { Key Findings }\end{array}$ \\
\hline $\begin{array}{l}\text { APIC. (2015). APIC guide to preventing CLABSI. Retrieved from } \\
\text { http://apic.org/Resource_TinyMceFileManager/2015/APIC_CLABSI_WE } \\
\text { B.pdf }\end{array}$ & $\begin{array}{l}\text { Level IV: } \\
\text { Clinical } \\
\text { guideline, } \\
\text { High Quality }\end{array}$ & N/A & N/A & None & $\begin{array}{l}\text { Reduction of } \\
\text { CLABSI } \\
\text { through the } \\
\text { practice of the } \\
\text { clinical } \\
\text { guideline } \\
\text { presented }\end{array}$ & $\begin{array}{l}\text { State, } \\
\text { regional, and } \\
\text { national } \\
\text { initiatives } \\
\text { have been } \\
\text { launched to } \\
\text { address } \\
\text { CLABSI }\end{array}$ \\
\hline $\begin{array}{l}\text { Bell, T., \& O'Grady, N. P. (2017). Prevention of central line-associated } \\
\text { bloodstream infections. Infectious disease clinics of North America, 31(3), } \\
\text { 551-559. https://doi.org/10.1016/j.idc.2017.05.007 }\end{array}$ & $\begin{array}{l}\text { Level V: } \\
\text { Integrative } \\
\text { Review, } \\
\text { High Quality }\end{array}$ & $\begin{array}{l}\text { Intensive } \\
\text { Care Unit }\end{array}$ & $\begin{array}{l}\text { Combination } \\
\text { of guideline } \\
\text { implementatio } \\
\mathrm{n}\end{array}$ & None & $\begin{array}{c}\text { Compliance } \\
\text { with CLABSI } \\
\text { reduction } \\
\text { guideline }\end{array}$ & $\begin{array}{l}\text { Insertion } \\
\text { strategies } \\
\text { including } \\
\text { education and } \\
\text { training of those } \\
\text { who insert } \\
\text { catheters, use of } \\
\text { chlorhexidine for } \\
\text { skin antisepsis, } \\
\text { and } \\
\text { use of maximal } \\
\text { sterile barrier } \\
\text { precautions have } \\
\text { a long record of } \\
\text { preventing } \\
\text { CLABSI. }\end{array}$ \\
\hline
\end{tabular}




\begin{tabular}{|c|c|c|c|c|c|c|}
\hline Citation & $\begin{array}{l}\text { Design, Level } \\
\text { Quality Grade }\end{array}$ & $\begin{array}{c}\text { Sample } \\
\text { Sample size }\end{array}$ & $\begin{array}{c}\text { Intervention } \\
\text { Comparison } \\
\text { (Definitions } \\
\text { should include } \\
\text { any specific } \\
\text { research tools } \\
\text { used along with } \\
\text { reliability \& } \\
\text { validity) }\end{array}$ & $\begin{array}{l}\text { Theoretical } \\
\text { Foundation }\end{array}$ & $\begin{array}{l}\text { Outcome } \\
\text { Definition }\end{array}$ & $\begin{array}{c}\text { Usefulness } \\
\text { Results } \\
\text { Key Findings }\end{array}$ \\
\hline $\begin{array}{l}\text { Boyce, J. M., Nadeau, J., Dumigan, D., Miller, D., Dubowsky, C., } \\
\text { Reilly, L., \& Hannon, C. V. (2013). Obtaining blood cultures by } \\
\text { venipuncture versus from central lines: impact on blood culture } \\
\text { contamination rates and potential effect on central line-associated } \\
\text { bloodstream infection reporting. Infection control and hospital } \\
\text { epidemiology, 34(10), 1042-1047. } \\
\text { https://doi.org/10.1086/673142 }\end{array}$ & $\begin{array}{l}\text { Observational } \\
\text { study, Level } \\
\text { I: } \\
\text { Experimenta } \\
\text { 1, High } \\
\text { Quality }\end{array}$ & $\begin{array}{l}\text { 500-bed } \\
\text { universityaffiliated } \\
\text { hospital. }\end{array}$ & $\begin{array}{l}\text { Implementing an } \\
\text { institutional } \\
\text { policy to } \\
\text { minimize blood } \\
\text { culture specimens } \\
\text { drawn from } \\
\text { central lines and } \\
\text { training IV nurses } \\
\text { to obtain blood } \\
\text { culture specimens } \\
\text { when the } \\
\text { phlebotomist } \\
\text { can't }\end{array}$ & None & $\begin{array}{l}\text { A new blood } \\
\text { culture policy } \\
\text { discouraged } \\
\text { drawing blood } \\
\text { samples from } \\
\text { central lines } \\
\text { reduces } \\
\text { CLABSI }\end{array}$ & $\begin{array}{l}\text { Multiple } \\
\text { interventions } \\
\text { resulted in a } \\
\text { reduction in } \\
\text { blood culture } \\
\text { contamination } \\
\text { rates and } \\
\text { substantial cost } \\
\text { savings to the } \\
\text { hospital, and } \\
\text { they may have } \\
\text { reduced the } \\
\text { number of } \\
\text { reportable } \\
\text { CLABSIs. }\end{array}$ \\
\hline $\begin{array}{l}\text { DeVries, M. (2019). Revisiting CLABSI prevention strategies: Part } 2 . \\
\text { Retrieved from https://www.myamericannurse.com/revisiting- } \\
\text { clabsiprevention-strategies-part-2/ }\end{array}$ & $\begin{array}{l}\text { Level V: } \\
\text { Expert } \\
\text { Opinion, } \\
\text { High Quality }\end{array}$ & N/A & $\begin{array}{l}\text { Staff involvement } \\
\text { in reviewing } \\
\text { CLABSI cases } \\
\text { and the policies } \\
\text { and process } \\
\text { measures that } \\
\text { help prevent } \\
\text { infections can } \\
\text { help focus the } \\
\text { team on ensuring } \\
\text { that the right care } \\
\text { is provided for } \\
\text { every patient, } \\
\text { every line, every } \\
\text { single time. }\end{array}$ & None & $\begin{array}{l}\text { Uncovering } \\
\text { the cause of } \\
\text { the CLABSI } \\
\text { and } \\
\text { developing an } \\
\text { action plan } \\
\text { are key steps } \\
\text { to preventing } \\
\text { future } \\
\text { infections. }\end{array}$ & $\begin{array}{l}\text { Central line } \\
\text { care also } \\
\text { should include } \\
\text { daily review of } \\
\text { its necessity. } \\
\text { Discontinuatio } \\
\text { n of central } \\
\text { line results to } \\
\text { reduced } \\
\text { CLABSI }\end{array}$ \\
\hline
\end{tabular}




\begin{tabular}{|c|c|c|c|c|c|c|}
\hline Citation & $\begin{array}{l}\text { Design, Level } \\
\text { Quality Grade }\end{array}$ & $\begin{array}{c}\text { Sample } \\
\text { Sample size }\end{array}$ & $\begin{array}{l}\text { Intervention } \\
\text { Comparison } \\
\text { (Definitions } \\
\text { should include } \\
\text { any specific } \\
\text { research tools } \\
\text { used along with } \\
\text { reliability \& } \\
\text { validity) }\end{array}$ & $\begin{array}{l}\text { Theoretical } \\
\text { Foundation }\end{array}$ & $\begin{array}{l}\text { Outcome } \\
\text { Definition }\end{array}$ & $\begin{array}{l}\text { Usefulness } \\
\text { Results } \\
\text { Key Findings }\end{array}$ \\
\hline $\begin{array}{l}\text { Haddadin, Y., Annamaraju, P., \& Regunath, H. (2020). Central line } \\
\text { associated blood stream } \\
\text { infections (CLABSI). In: StatPearls [Internet]. Retrieved from } \\
\text { https://www.ncbi.nlm.nih.gov/books/NBK430891/\# }\end{array}$ & $\begin{array}{l}\text { Level V: } \\
\text { Integrative } \\
\text { Review, } \\
\text { Good } \\
\text { Quality }\end{array}$ & $\begin{array}{l}\text { Patients with } \\
\text { central } \\
\text { venous } \\
\text { catheters }\end{array}$ & $\begin{array}{l}\text { CLABSI } \\
\text { Guideline }\end{array}$ & None & $\begin{array}{l}\text { Only through } \\
\text { best practices, } \\
\text { protocols, } \\
\text { checklists, and } \\
\text { establishing a } \\
\text { culture of } \\
\text { patient safety } \\
\text { in healthcare } \\
\text { institutions } \\
\text { can one } \\
\text { reduce } \\
\text { CLABSI to } \\
\text { zero }\end{array}$ & $\begin{array}{l}\text { Tunneled } \\
\text { hemodialysis } \\
\text { catheters are } \\
\text { prone to } \\
\text { infection as } \\
\text { well }\end{array}$ \\
\hline $\begin{array}{l}\text { Kuriakose, L. (2020). Decreasing central line associated } \\
\text { bloodstream infection through limiting the use of central } \\
\text { venous catheters for routine blood draws. Journal of Doctoral } \\
\text { Nursing Practice,13(2). http://dx.doi.org/10.1891/JDNP-D-19- } \\
00071\end{array}$ & $\begin{array}{l}\text { Quality } \\
\text { Improvement, } \\
\text { Level V: } \\
\text { Organization } \\
\text { Experience, } \\
\text { High Quality }\end{array}$ & $\begin{array}{l}20 \text {-bed } \\
\text { cardiac } \\
\text { intensive care } \\
\text { unit }\end{array}$ & $\begin{array}{l}\text { Limiting the } \\
\text { use of central } \\
\text { venous } \\
\text { catheters } \\
\text { (CVC) for } \\
\text { routine blood } \\
\text { draws }\end{array}$ & None & $\begin{array}{l}\text { Reduced } \\
\text { CLABSI from } \\
\text { one case to } \\
\text { zero; and zero } \\
\text { cases for three } \\
\text { months }\end{array}$ & $\begin{array}{l}\text { Educating staff } \\
\text { about limiting } \\
\text { the use of } \\
\text { CVC resulted } \\
\text { to decrease in } \\
\text { accessing } \\
\text { CVCs for } \\
\text { routine blood } \\
\text { work, and } \\
\text { arterial lines } \\
\text { and } \\
\text { venipunctures } \\
\text { were used for } \\
\text { routine blood } \\
\text { draws. }\end{array}$ \\
\hline
\end{tabular}




\begin{tabular}{|c|c|c|c|c|c|c|}
\hline Citation & $\begin{array}{l}\text { Design, Level } \\
\text { Quality Grade }\end{array}$ & $\begin{array}{c}\text { Sample } \\
\text { Sample size }\end{array}$ & $\begin{array}{l}\text { Intervention } \\
\text { Comparison } \\
\text { (Definitions } \\
\text { should include } \\
\text { any specific } \\
\text { research tools } \\
\text { used along with } \\
\text { reliability \& } \\
\text { validity) }\end{array}$ & $\begin{array}{l}\text { Theoretical } \\
\text { Foundation }\end{array}$ & $\begin{array}{l}\text { Outcome } \\
\text { Definition }\end{array}$ & $\begin{array}{l}\text { Usefulness } \\
\text { Results } \\
\text { Key Findings }\end{array}$ \\
\hline $\begin{array}{l}\text { Ling, M. L., Apisarnthanarak, A., Jaggi, N., Harrington, G., Morikane, K., } \\
\text { Thu, 1., Ching, P., Villanueva, V., Zong, Z., Jeong, J. S., \& Lee, C. M. } \\
\text { (2016). APSIC guide for prevention of Central Line Associated } \\
\text { Bloodstream Infections (CLABSI). Antimicrobial resistance and infection } \\
\text { control, 5, 16. https://doi.org/10.1186/s13756-016-0116-5 }\end{array}$ & $\begin{array}{l}\text { Clinical } \\
\text { Guideline, } \\
\text { Level IV, } \\
\text { High Quality }\end{array}$ & $\begin{array}{l}11 \text { Hospitals } \\
\text { at Asia } \\
\text { Pacific } \\
\text { region }\end{array}$ & $\begin{array}{l}\text { Identify } \\
\text { different } \\
\text { CLABSI } \\
\text { prevention } \\
\text { practice }\end{array}$ & None & $\begin{array}{l}\text { CLABSIs } \\
\text { are largely } \\
\text { preventable } \\
\text { when } \\
\text { evidencebased } \\
\text { guidelines are } \\
\text { followed }\end{array}$ & $\begin{array}{l}\text { CLABSI is one } \\
\text { of the most } \\
\text { common and } \\
\text { yet preventable } \\
\text { healthcare } \\
\text { associated } \\
\text { infections. }\end{array}$ \\
\hline $\begin{array}{l}\text { Page, J., Tremblay, M., Nicholas, C., \& James, T. A. (2016). Reducing } \\
\text { oncology unit central line-associated bloodstream infections: Initial results } \\
\text { of a simulation-based educational intervention. Journal of oncology } \\
\text { practice, 12(1), e83-e87. https://doi.org/10.1200/JOP.2015.005751 }\end{array}$ & $\begin{array}{l}\text { Level I: } \\
\text { Experimenta } \\
\text { 1, Good } \\
\text { Quality }\end{array}$ & $\begin{array}{l}\text { Adult } \\
\text { inpatient } \\
\text { hematology } \\
\text { - oncology } \\
\text { unit in an } \\
\text { academic } \\
\text { medical } \\
\text { center. }\end{array}$ & $\begin{array}{l}\text { 31-question } \\
\text { multiple } \\
\text { choice pretest } \\
\text { was developed } \\
\text { to } \\
\text { identify } \\
\text { knowledge } \\
\text { deficits } \\
\text { regarding } \\
\text { central line } \\
\text { standards of } \\
\text { care. This test } \\
\text { was } \\
\text { mandatory for } \\
\text { all staff nurses } \\
\text { and was } \\
\text { completed }\end{array}$ & $\begin{array}{l}\text { Simulated } \\
\text { central line } \\
\text { care model }\end{array}$ & $\begin{array}{l}\text { A targeted } \\
\text { educational } \\
\text { intervention } \\
\text { using a simulated } \\
\text { central line care } \\
\text { model improved } \\
\text { competence in } \\
\text { central line care } \\
\text { and resulted in } \\
\text { decreased } \\
\text { CLABSI rates } \\
\text { for inpatient } \\
\text { oncology } \\
\text { patients. }\end{array}$ & $\begin{array}{l}\text { Use of } \\
\text { individual } \\
\text { training via } \\
\text { simulation } \\
\text { and return } \\
\text { demonstratio } \\
\text { n proved to } \\
\text { be a } \\
\text { successful } \\
\text { educational } \\
\text { method. }\end{array}$ \\
\hline
\end{tabular}




\begin{tabular}{|c|c|c|c|c|c|c|}
\hline Citation & $\begin{array}{l}\text { Design, Level } \\
\text { Quality Grade }\end{array}$ & $\begin{array}{c}\text { Sample } \\
\text { Sample size }\end{array}$ & $\begin{array}{l}\text { Intervention } \\
\text { Comparison } \\
\text { (Definitions } \\
\text { should include } \\
\text { any specific } \\
\text { research tools } \\
\text { used along with } \\
\text { reliability \& } \\
\text { validity) }\end{array}$ & $\begin{array}{l}\text { Theoretical } \\
\text { Foundation }\end{array}$ & $\begin{array}{l}\text { Outcome } \\
\text { Definition }\end{array}$ & $\begin{array}{l}\text { Usefulness } \\
\text { Results } \\
\text { Key Findings }\end{array}$ \\
\hline $\begin{array}{l}\text { Stevens, V., Geiger, K., Concannon, C., Nelson, R., Brown, J., \& Dumyati, } \\
\text { G. (2013). Inpatient costs, mortality and 30-day re-admission in patients } \\
\text { with central-line-associated bloodstream infections. Clinical Microbiology } \\
\text { and Infection, 20, 0318-0324. doi: 10.1111/1469-0691.12407. }\end{array}$ & $\begin{array}{l}\text { Retrospectiv } \\
\text { e cohort } \\
\text { study, } \\
\text { Level III: } \\
\text { Exploratory, } \\
\text { Good } \\
\text { Quality }\end{array}$ & $\begin{array}{l}398 \text { patients } \\
\text { hospitalized } \\
\text { at the } \\
\text { University of } \\
\text { Rochester } \\
\text { Medical } \\
\text { Center }\end{array}$ & $\begin{array}{l}\text { Patients with } \\
\text { CLABSI and } \\
\text { without } \\
\text { CLABSI }\end{array}$ & None & $\begin{array}{l}\text { The primary } \\
\text { outcome of } \\
\text { this study was } \\
\text { inpatient costs. } \\
\text { The secondary } \\
\text { outcomes in } \\
\text { this study were } \\
\text { all-cause in- } \\
\text { hospital } \\
\text { mortality and } \\
\text { 30-day } \\
\text { readmission } \\
\text { rate }\end{array}$ & $\begin{array}{l}\text { The unadjusted } \\
\text { difference in } \\
\text { variable } \\
\text { hospital costs } \\
\text { between } \\
\text { patients with } \\
\text { CLABSI and } \\
\text { those without } \\
\text { CLABSI } \\
\text { was c. } \$ 56 \\
800 \text {. CLABSI } \\
\text { patients were } \\
\text { at higher risk } \\
\text { of dying in the } \\
\text { hospital, but } \\
30 \text {-day } \\
\text { readmission } \\
\text { rates were } \\
\text { similar } \\
\text { between the } \\
\text { two groups. }\end{array}$ \\
\hline
\end{tabular}




\section{Truini-Pittman, L., Sullivan, L., Pedersen, K., Mistry, T., \& Williams, J.}

(2015). Reducing central line-associated bloodstream infections.

Retrieved from http://www.oncnursingnews.com/publications/oncologynurse/2015/may-

2015/reducing-centrallineassociated- bloodstream-

infections

\begin{tabular}{|c|c|c|c|c|c|}
\hline $\begin{array}{l}\text { Quantitative } \\
\text { Level I: } \\
\text { Experimenta } \\
1 \text { (RCT), } \\
\text { Good } \\
\text { Quality }\end{array}$ & $\begin{array}{l}\text { Two } \\
\text { Oncology } \\
\text { unit patients }\end{array}$ & $\begin{array}{l}\text { Algorithm that } \\
\text { gave } \\
\text { consideration to } \\
\text { the clinicians' } \\
\text { concerns and } \\
\text { minimized } \\
\text { the } \\
\text { number of } \\
\text { central line } \\
\text { cultures drawn. }\end{array}$ & None & $\begin{array}{l}\text { CLABSI rate } \\
\text { decreased } \\
\text { from } 3.4 \text { to } \\
2.1 \\
\text { infections } / 100 \\
0 \text { device days } \\
\text { for the } \\
\text { following } 6 \\
\text { months }\end{array}$ & $\begin{array}{l}\text { Engagement of } \\
\text { the patient and } \\
\text { interdisciplinar } \\
\text { y team was } \\
\text { critical to the } \\
\text { success of this } \\
\text { project. }\end{array}$ \\
\hline
\end{tabular}

\begin{tabular}{|c|c|c|c|c|c|c|}
\hline Citation & $\begin{array}{l}\text { Design, Level } \\
\text { Quality Grade }\end{array}$ & $\begin{array}{c}\text { Sample } \\
\text { Sample size }\end{array}$ & $\begin{array}{c}\text { Intervention } \\
\text { Comparison } \\
\text { (Definitions } \\
\text { should include } \\
\text { any specific } \\
\text { research tools } \\
\text { used along with } \\
\text { reliability \& } \\
\text { validity) }\end{array}$ & $\begin{array}{l}\text { Theoretical } \\
\text { Foundation }\end{array}$ & $\begin{array}{l}\text { Outcome } \\
\text { Definition }\end{array}$ & $\begin{array}{l}\text { Usefulness } \\
\text { Results } \\
\text { Key Findings }\end{array}$ \\
\hline $\begin{array}{l}\text { Valencia, C., Hammami, N., Agodi, A. et al. (2016). Poor adherence to } \\
\text { guidelines for preventing central line-associated bloodstream infections } \\
\text { (CLABSI): results of a worldwide survey. Antimicrobial Resistance } \\
\text { Infection Control, 5(49). https://doi.org/10.1186/s13756-016-0139-y }\end{array}$ & $\begin{array}{l}\text { Qualitative, } \\
\text { Level III, } \\
\text { High/Good } \\
\text { Quality }\end{array}$ & $\begin{array}{l}3407 \text { Medical } \\
\text { doctors and } \\
\text { nurses working } \\
\text { in } \\
\text { ICUs }\end{array}$ & $\begin{array}{l}\text { online } \\
\text { questionnaire } \\
\text { was made } \\
\text { available to } \\
\text { medical } \\
\text { doctors and } \\
\text { nurses } \\
\text { working in } \\
\text { ICUs }\end{array}$ & None & $\begin{array}{l}\text { This study has } \\
\text { identified areas } \\
\text { for improvement } \\
\text { in CLABSI } \\
\text { prevention } \\
\text { practices linked } \\
\text { to CL insertion } \\
\text { and maintenance. }\end{array}$ & $\begin{array}{l}\text { Priorities for } \\
\text { intervention } \\
\text { differ between } \\
\text { countries. }\end{array}$ \\
\hline $\begin{array}{l}\text { Williamson, K., Gonzales, L., Neusbaum, A., \& Messing, J. (2017). } \\
\text { Reducing the risk of central line-associated bloodstream infections. } \\
\text { American Nurse Today, } 12(5) . \text { Retrieved from } \\
\text { https://www.myamericannurse.com/reducing-risk-centralline- } \\
\text { associated-bloodstream-infections/ }\end{array}$ & $\begin{array}{l}\text { Level V: } \\
\text { Clinician } \\
\text { experience, } \\
\text { Good } \\
\text { Quality }\end{array}$ & $\begin{array}{l}\text { 49-bed } \\
\text { medicalsurgical } \\
\text { unit }\end{array}$ & $\begin{array}{l}\text { No Central } \\
\text { Blood Line } \\
\text { Draw program }\end{array}$ & $\begin{array}{c}\text { Plan-Do- } \\
\text { Check- } \\
\text { Act } \\
\text { qualityimproveme } \\
\text { nt model }\end{array}$ & $\begin{array}{l}\text { No Central } \\
\text { Line } \\
\text { Blood Draw } \\
\text { in October } \\
2014, \text { no } \\
\text { participating } \\
\text { patient has } \\
\text { acquired a } \\
\text { CLABSI }\end{array}$ & $\begin{array}{l}\text { Implementation } \\
\text { of this innovative } \\
\text { process allowed } \\
\text { for } \\
\text { interprofessional } \\
\text { collaboration and } \\
\text { decreased the risk } \\
\text { of patients } \\
\text { acquiring } \\
\text { CLABSIs. }\end{array}$ \\
\hline
\end{tabular}


Woodward, B., \& Umberger, R. (2016). Review of best practices for CLABSI prevention and the impact of recent

Level V:

Level V:

United States

legislation on CLABSI reporting. SAGE Open, 1-7. Retrieved

Integrati

Healthcare

Review of

review,

organization

best practice

None

prevention

new federal

legislation such

as the

https://journals.sagepub.com/doi/10.1177/2158244016677747

Good

ACA has created

gaps in the

knowledge about

how the use of

incentives and

penalties affect

reporting and

incidence of

HAIs

such as

CLABSIs

Laws an

legal

guidelines

affect the

reporting of

CLABSI 
Table

\section{Appendix C}

3

Summary of Systematic Reviews (SR)

\begin{tabular}{|c|c|c|c|c|c|c|c|}
\hline Citation & $\begin{array}{l}\text { Quality } \\
\text { Grade }\end{array}$ & Question & $\begin{array}{l}\text { Search } \\
\text { Strategy }\end{array}$ & $\begin{array}{c}\text { Inclusion/ } \\
\text { Exclusion Criteria }\end{array}$ & $\begin{array}{c}\text { Data Extraction } \\
\text { and Analysis }\end{array}$ & $\begin{array}{c}\text { Key } \\
\text { Findings }\end{array}$ & \begin{tabular}{|c|} 
Usefulness/Recom \\
mendation/ \\
Implications
\end{tabular} \\
\hline \begin{tabular}{|l} 
Blot, K., Bergs, J., Vogelaers, D., Blot, S., \& \\
Vandijck, D. (2014). Prevention of central line- \\
associated bloodstream infections through quality \\
improvement interventions: A systematic review and \\
meta-analysis. Clinical Infectious Diseases, 59(1), \\
$96-105$. https://doi.org/10.1093/cid/ciu239
\end{tabular} & $\begin{array}{c}\text { Level I: } \\
\text { Systematic } \\
\text { Review, } \\
\text { High }\end{array}$ & $\begin{array}{l}\text { How does } \\
\text { QI impact } \\
\text { CLABSI } \\
\text { rate in ICU } \\
\text { patients? }\end{array}$ & $\begin{array}{c}\text { Medline was } \\
\text { systematicall } \\
\text { y searched } \\
\text { (1995-June } \\
\text { 2012) }\end{array}$ & $\begin{array}{c}\text { Before-after, } \\
\text { interrupted time } \\
\text { series (ITS), } \\
\text { controlled before- } \\
\text { after, } \\
\text { nonrandomized } \\
\text { controlled trial, or } \\
\text { randomized } \\
\text { controlled trial } \\
\text { study designs } \\
\end{array}$ & $\begin{array}{c}\text { Extracted data } \\
\text { included author and } \\
\text { year of publication, } \\
\text { settings and study } \\
\text { populations, study } \\
\text { designs and } \\
\text { periods, quality } \\
\text { improvement and } \\
\text { preventive } \\
\text { interventions } \\
\text { implemented in the } \\
\text { baseline and } \\
\text { intervention } \\
\text { periods, } \\
\text { compliance } \\
\text { measures, number } \\
\text { of CLABSI and } \\
\text { catheter-days, and } \\
\text { applied CLABSI } \\
\text { definitions }\end{array}$ & $\begin{array}{c}\text { Infection } \\
\text { rate } \\
\text { decrease } \\
\text { was more } \\
\text { pronounced } \\
\text { in studies } \\
\text { using } \\
\text { bundles or } \\
\text { checklists }\end{array}$ & $\begin{array}{c}\text { Impact of quality } \\
\text { improvement } \\
\text { interventions on } \\
\text { central line-- } \\
\text { associated } \\
\text { bloodstream } \\
\text { infections in adult } \\
\text { intensive care units. }\end{array}$ \\
\hline
\end{tabular}


Table

Patel, P. K., Gupta, A., Vaughn, V. M., Mann, J. D., Ameling, J. M., \& Meddings, J. (2018). Review of

Strategies to Reduce Central Line-Associated

Bloodstream Infection (CLABSI) and

CatheterAssociated Urinary Tract Infection (CAUTI) in

Adult ICUs. Journal of hospital medicine, 13(2), 105-116. https://doi.org/10.12788/jhm.2856

\begin{tabular}{|c|c|c|c|c|c|c|}
\hline $\begin{array}{c}\text { Level I: } \\
\text { Systematic } \\
\text { Review, } \\
\text { High }\end{array}$ & $\begin{array}{l}\text { How to } \\
\text { reduce } \\
\text { CLABSI } \\
\text { and } \\
\text { CAUTI? }\end{array}$ & $\begin{array}{c}\text { PubMed and } \\
\text { Cochrane } \\
\text { databases } \\
\text { from } \\
\text { their } \\
\text { inception } \\
\text { to October of } \\
2015 \text { using } \\
\text { Medical } \\
\text { Subject } \\
\text { Headings } \\
\text { (MeSHs) }\end{array}$ & \begin{tabular}{|} 
Included randomized \\
and nonrandomized \\
studies that \\
implemented \\
at least 1 intervention to \\
prevent CLABSI or \\
CAUTI \\
in an adult ICU, \\
\\
Excluded general \\
ward, \\
outpatient/ambulatory, \\
and neonatal/pediatric \\
settings
\end{tabular} & $\begin{array}{l}\text { The search } \\
\text { algorithm } \\
\text { identified } 634 \\
\text { records and } \\
\text { narrowed down to } \\
\text { this meta-analysis } \\
\text { of } 43 \text { studies, } \\
\text { involving } 584 \text { ICU }\end{array}$ & $\begin{array}{c}\text { Quality } \\
\text { improveme } \\
\text { nt } \\
\text { interventio } \\
\text { ns reduce } \\
\text { CLABSI in } \\
\text { adult ICUs }\end{array}$ & $\begin{array}{l}\text { Further research } \\
\text { should assess } \\
\text { requirements for } \\
\text { successful } \\
\text { adaptation of } \\
\text { quality } \\
\text { improvement } \\
\text { interventions, for } \\
\text { example, through } \\
\text { improvement } \\
\text { systems, over longer } \\
\text { follow- up periods. }\end{array}$ \\
\hline
\end{tabular}

Legend: 
Table

\section{Appendix D}

4

Summary of Primary Research Evidence

\begin{tabular}{|c|c|c|}
\hline LEVEL & QUALITY GRADE & LITERATURE (AUTHOR, YEAR PUBLISHED, TITLE) \\
\hline $\mathbf{I}$ & $\begin{array}{l}\text { High Quality } \\
\text { Good Quality } \\
\text { Good Quality }\end{array}$ & $\begin{array}{l}\text { Boyce, J. M., Nadeau, J., Dumigan, D., Miller, D., Dubowsky, C., Reilly, L., } \\
\text { \& Hannon, C. V. (2013). Obtaining blood cultures by venipuncture versus } \\
\text { from central lines: impact on blood culture contamination rates and potential } \\
\text { effect on central line-associated bloodstream infection reporting } \\
\text { Page, J., Tremblay, M., Nicholas, C., \& James, T. A. (2016). Reducing } \\
\text { oncology unit central line-associated bloodstream infections: Initial results of } \\
\text { a simulation-based educational intervention } \\
\text { Truini-Pittman, L., Sullivan, L., Pedersen, K., Mistry, T., \& Williams, J. } \\
\text { (2015). Reducing central line-associated bloodstream infections }\end{array}$ \\
\hline III & $\begin{array}{c}\text { Good Quality } \\
\text { High/Good Quality }\end{array}$ & $\begin{array}{l}\text { Stevens, V., Geiger, K., Concannon, C., Nelson, R., Brown, J., \& Dumyati, } \\
\text { G. (2013). Inpatient costs, mortality and 30-day re-admission in patients with } \\
\text { central-line-associated blood stream infections } \\
\text { Valencia, C., Hammami, N., Agodi, A. et al. (2016). Poor adherence to } \\
\text { guidelines for preventing central line-associated bloodstream infections } \\
\text { (CLABSI): results of a worldwide survey }\end{array}$ \\
\hline IV & $\begin{array}{l}\text { High Quality } \\
\text { High Quality }\end{array}$ & $\begin{array}{l}\text { APIC. (2015). APIC guide to preventing CLABSI } \\
\text { Ling, M. L., Apisarnthanarak, A., Jaggi, N., Harrington, G., Morikane, K., } \\
\text { Thu, l., Ching, P., Villanueva, V., Zong, Z., Jeong, J. S., \& Lee, C. M. } \\
\text { (2016). APSIC guide for prevention of Central Line Associated Bloodstream } \\
\text { Infections (CLABSI) }\end{array}$ \\
\hline $\mathbf{V}$ & $\begin{array}{l}\text { High Quality } \\
\text { High Quality } \\
\text { Good Quality }\end{array}$ & $\begin{array}{l}\text { Bell, T., \& O'Grady, N. P. (2017). Prevention of central line-associated } \\
\text { bloodstream infections } \\
\text { DeVries, M. (2019). Revisiting CLABSI prevention strategies: Part } 2 \\
\text { Haddadin, Y., Annamaraju, P., \& Regunath, H. (2020). Central } \\
\text { line associated blood stream infections (CLABSI) } \\
\text { Kuriakose, L. (2020). Decreasing central line } \\
\text { associated bloodstream infection through limiting the } \\
\text { use of central venous } \\
\text { catheters for routine blood draws } \\
\text { Williamson, K., Gonzales, L., Neusbaum, A., \& Messing, J. (2017). } \\
\text { Reducing the risk of central } \\
\text { line-associated bloodstream infections } \\
\text { Woodward, B., \& Umberger, R. (2016). Review of best practices for } \\
\text { CLABSI prevention and the } \\
\text { impact of recent legislation on CLABSI reporting }\end{array}$ \\
\hline
\end{tabular}




\section{APPENDIX E}

5

Summary of Systematic Reviews

\begin{tabular}{|c|c|l|}
\hline LEVEL & QUALITY GRADE & \multicolumn{1}{c|}{ LITERATURE (AUTHOR, YEAR PUBLISHED, TITLE) } \\
\hline I & High Quality & $\begin{array}{l}\text { Blot, K., Bergs, J., Vogelaers, D., Blot, S., \& Vandijck, D. (2014). Prevention } \\
\text { of central line-associated blood stream infections through quality } \\
\text { improvement interventions: A systematic review and meta-analysis }\end{array}$ \\
& $\begin{array}{l}\text { Patel, P. K., Gupta, A., Vaughn, V. M., Mann, J. D., Ameling, J. M., \& } \\
\text { Meddings, J. (2018). Review of Strategies to Reduce Central Line-Associated } \\
\text { Bloodstream Infection (CLABSI) and Catheter-Associated Urinary Tract } \\
\text { Infection (CAUTI) in Adult ICUs }\end{array}$ \\
\hline
\end{tabular}




\section{Table}

\section{Table 6}

APPENDIX F

SWOT Analysis

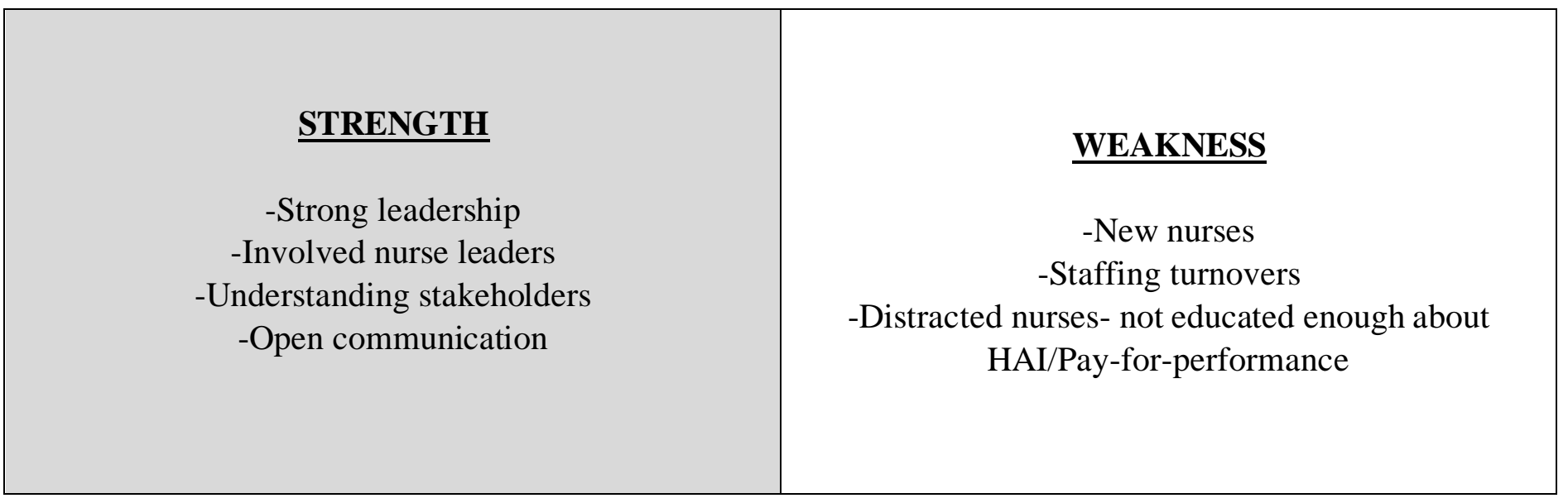




\section{OPPORTUNITIES}

-Update Policies

-Adapting new innovative interventions

\section{THREATS}

-COVID-19 surge -Staffing shortages

-Physician resistance

-Long term nursing staff resistance to change 


\section{Figure 1}

\section{APPENDIX G}

\section{CVC Blood Draw Process}

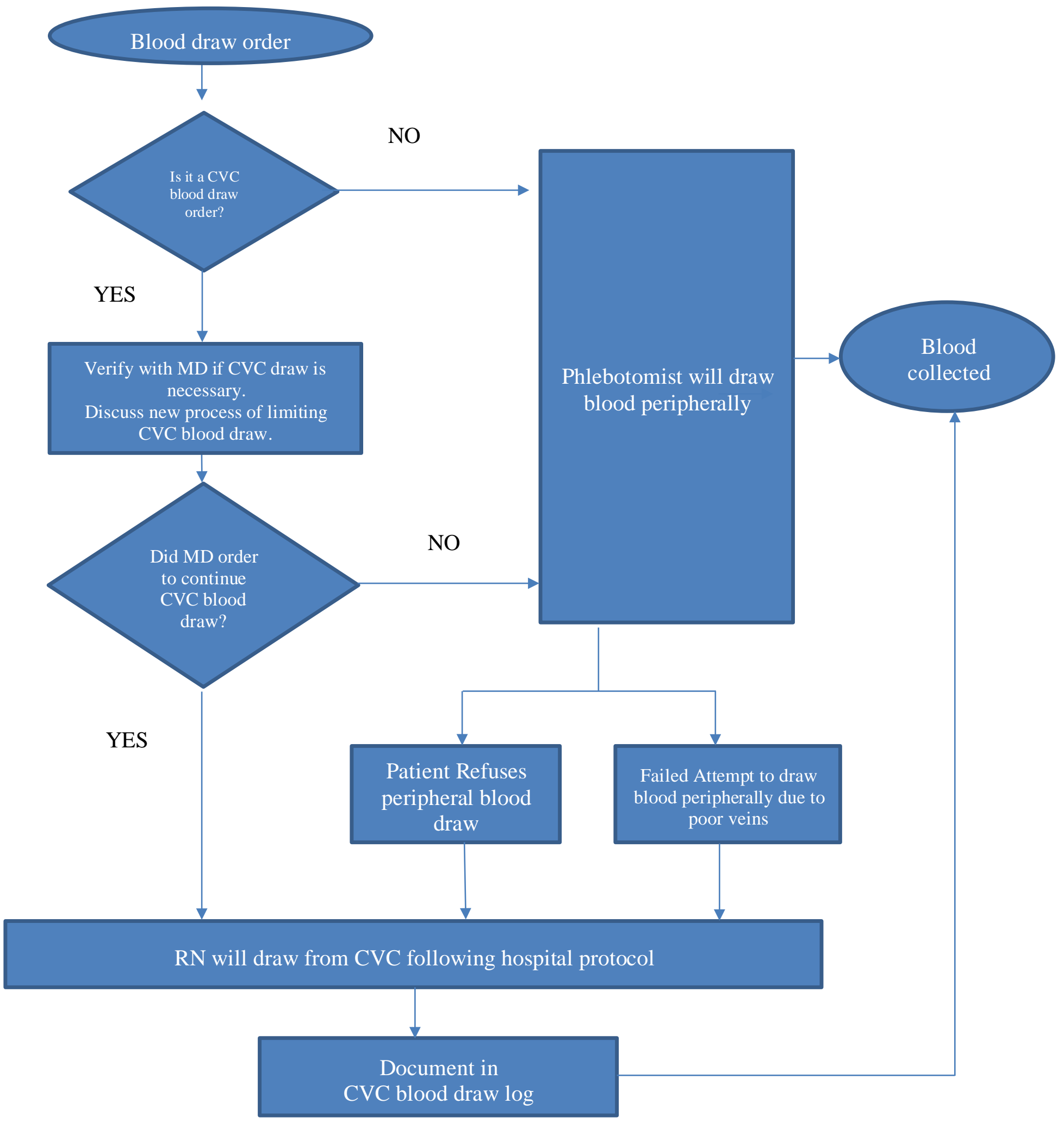

\section{Instructions:}


Follow the flowchart to promote the limitation of central venous catheter (CVC) blood draw. The goal of the process is to reduce the central line-associated bloodstream infection (CLABSI) rate by reducing the $\mathrm{CVC}$ contact and manipulation.

\section{Steps:}

1. Identify if the blood draw order is through CVC or peripheral access.

2. If it is not a CVC blood draw order, the phlebotomist will conduct the blood draw through peripheral venipuncture.

Failure of the phlebotomist to perform peripheral venipuncture due to patient refusals or cases of hard sticks will result to the registered nurse to perform CVC draw per facility protocol (Steps 4 and 5).

3. If it is a CVC blood draw order, the nurse will contact the ordering physician to verify the necessity of CVC blood draw. Explain the project of reducing CLABSI through the process of limiting CVC blood draws.

a. If MD changes order to peripheral draw, follow Step 2.

b. If MD continues CVC blood draw order, follow Step 4.

4. The registered nurse will draw blood due to rare cases of exception from the CVC following hospital protocol.

Rare cases of exception are identified as CVC blood draws due to physician orders, emergent draw during codes or life-threatening events, poor veins of the patient, patient refusal of peripheral draws, and nurses' forgetting the new process.

5. Document the draw in the CVC blood drawn log. 


\section{APPENDIX H}

\section{Table 7}

CENTRAL VENOUS CATHETER BLOOD DRAW LOG

\begin{tabular}{|c|c|c|c|c|c|c|c|}
\hline Patient's RM\# & $\begin{array}{l}\text { Type of } \\
\text { Catheter }\end{array}$ & $\begin{array}{c}\text { Catheter } \\
\text { Insertion Site }\end{array}$ & $\begin{array}{c}\text { Catheter } \\
\text { Insertion Date }\end{array}$ & $\begin{array}{c}\text { CVC } \\
\text { Blood } \\
\text { Draw Date }\end{array}$ & $\begin{array}{c}\text { CVC Blood } \\
\text { Draw } \\
\text { Time }\end{array}$ & $\begin{array}{l}\quad \text { Reason for CVC Blood draw } \\
1 \text { MD order } \\
2 \text { Emergent draws } \\
3 \text { Forgot the new process } \\
4 \text { Pt refused peripheral draw } \\
5 \text { Poor veins }\end{array}$ & Comment \\
\hline & & & & & & & \\
\hline & & & & & & & \\
\hline & & & & & & & \\
\hline & & & & & & & \\
\hline & & & & & & & \\
\hline & & & & & & & \\
\hline & & & & & & & \\
\hline
\end{tabular}




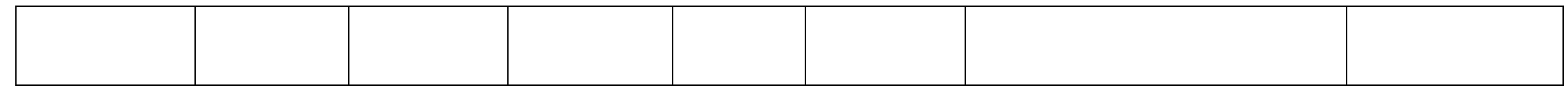

\section{APPENDIX I}

\section{Table 8}

CENTRAL VENOUS CATHETER TRACKING LOG

DATE:

\begin{tabular}{|c|c|c|c|c|c|c|c|c|c|}
\hline \multirow[b]{2}{*}{$\begin{array}{c}\text { Patient's } \\
\text { RM\# }\end{array}$} & \multirow[b]{2}{*}{ Diagnosis } & \multirow[b]{2}{*}{$\begin{array}{l}\text { Type of } \\
\text { Catheter }\end{array}$} & \multirow{2}{*}{$\begin{array}{c}\text { Catheter } \\
\text { Insertion } \\
\text { Site }\end{array}$} & \multirow{2}{*}{$\begin{array}{c}\text { Catheter } \\
\text { Insertion } \\
\text { Date }\end{array}$} & \multirow{2}{*}{$\begin{array}{c}\text { Catheter } \\
\text { Removal } \\
\text { Date }\end{array}$} & \multirow[b]{2}{*}{$\begin{array}{c}\text { Catheter } \\
\text { Days }\end{array}$} & \multicolumn{2}{|c|}{ Pt have CLABSI? } & \multirow[b]{2}{*}{ Comments } \\
\hline & & & & & & & $\begin{array}{c}\text { YES } \\
\text { (Date } \\
\text { Identified) }\end{array}$ & NO & \\
\hline & & & & & & & & & \\
\hline & & & & & & & & & \\
\hline & & & & & & & & & \\
\hline & & & & & & & & & \\
\hline & & & & & & & & & \\
\hline & & & & & & & & & \\
\hline & & & & & & & & & \\
\hline
\end{tabular}




\begin{tabular}{|l|l|l|l|l|l|l|l|l|l|}
\hline & & & & & & & & & \\
\hline & & & & & & & & & \\
\hline & & & & & & & & & \\
\hline
\end{tabular}

APPENDIX J Table 9

\section{Project Schedule Gantt Chart}

\begin{tabular}{|l|c|c|c|c|c|c|c|}
\hline \multicolumn{1}{|c|}{ Task } & Responsible \\
Party & Start & End & $\begin{array}{c}\text { January } \\
\mathbf{2 0 2 1}\end{array}$ & $\begin{array}{c}\text { February } \\
\mathbf{2 0 2 1}\end{array}$ & $\begin{array}{c}\text { March } \\
\mathbf{2 0 2 1}\end{array}$ & $\begin{array}{c}\text { April } \\
\mathbf{2 0 2 1}\end{array}$ & $\begin{array}{c}\text { May } \\
\mathbf{2 0 2 1}\end{array}$ \\
\hline Identifying project topic & $\begin{array}{c}\text { Project Manager } \\
\text { (PM) }\end{array}$ & $1 / 10 / 21$ & $1 / 10 / 21$ & & & \\
\hline $\begin{array}{l}\text { Literature search of evidence } \\
\text { Collecting statistics from state, } \\
\text { national, and global }\end{array}$ & PM & $1 / 10 / 21$ & $1 / 20 / 21$ & & & \\
\hline $\begin{array}{l}\text { Finalizing project proposal } \\
\text { Seek approval from CEO for } \\
\text { presenting project proposal to } \\
\text { stakeholders }\end{array}$ & PM/CEO & $2 / 15 / 21$ & $2 / 17 / 21$ & & & & \\
\hline
\end{tabular}




\begin{tabular}{|l|c|c|c|l|l|l|l|}
\hline $\begin{array}{l}\text { Presentation of Project to } \\
\text { Stakeholders }\end{array}$ & PM/CNO & $2 / 18 / 21$ & $2 / 19 / 21$ & & & & \\
\hline $\begin{array}{l}\text { Discussion of resource and budget } \\
\text { with CFO }\end{array}$ & PM/CFO & $2 / 22 / 21$ & $2 / 22 / 21$ & & & & \\
\hline Project Approval & $\begin{array}{c}\text { PM and } \\
\text { CEO/COO/CNO }\end{array}$ & $2 / 23 / 21$ & $2 / 23 / 21$ & & & & \\
\hline $\begin{array}{l}\text { Discussion of implementation plan } \\
\text { with COO and CNO }\end{array}$ & $\begin{array}{c}\text { PM and } \\
\text { COO/CNO }\end{array}$ & $2 / 24 / 21$ & $2 / 24 / 21$ & & & & \\
\hline
\end{tabular}

\begin{tabular}{|c|c|c|c|c|c|c|c|c|}
\hline Task & $\begin{array}{l}\text { Responsible } \\
\text { Party }\end{array}$ & Start & End & $\begin{array}{c}\text { January } \\
2021\end{array}$ & $\begin{array}{l}\text { February } \\
2021\end{array}$ & $\begin{array}{l}\text { March } \\
2021\end{array}$ & $\begin{array}{l}\text { April } \\
2021\end{array}$ & $\begin{array}{l}\text { May } \\
2021\end{array}$ \\
\hline $\begin{array}{l}\text { Review of Electronic Health } \\
\text { Record system-Cerner }\end{array}$ & PM and IT & $03 / 1 / 21$ & $03 / 1 / 21$ & & & & & \\
\hline $\begin{array}{l}\text { Discussion and education with } \\
\text { physicians about limiting } \\
\text { nonemergent orders for CVC } \\
\text { access }\end{array}$ & $\begin{array}{c}\text { PM, } \\
\text { CNO/Telemetry } \\
\text { Director and } \\
\text { Physicians } \\
\end{array}$ & $03 / 2 / 21$ & $3 / 2 / 21$ & & & & & \\
\hline $\begin{array}{l}\text { Training of staff in proper } \\
\text { screening of blood draw orders }\end{array}$ & $\begin{array}{l}\text { Casey/Telemetry } \\
\text { Director and } \\
\text { Manger }\end{array}$ & $3 / 3 / 21$ & $3 / 10 / 21$ & & & & & \\
\hline $\begin{array}{l}\text { Regular ongoing inservice and } \\
\text { follow-up on limiting CVC blood } \\
\text { draw orders and bundling lab } \\
\text { draws }\end{array}$ & Casey/ & $3 / 3 / 21$ & $4 / 26 / 21$ & & & & & \\
\hline $\begin{array}{l}\text { Patient support- discussing } \\
\text { indication and rationale of limiting } \\
\text { CVC Blood draws }\end{array}$ & $\begin{array}{l}\text { Charge and Staff } \\
\text { Nurses }\end{array}$ & $3 / 2 / 21$ & $4 / 26 / 21$ & & & & & \\
\hline
\end{tabular}




\begin{tabular}{|c|c|c|c|c|c|c|c|c|}
\hline $\begin{array}{l}\text { Performance of } \\
\text { intervention/limiting CVC blood } \\
\text { draws }\end{array}$ & Staff Nurses & $3 / 8 / 21$ & $4 / 30 / 21$ & & & & & \\
\hline $\begin{array}{l}\text { CVC audit through reports on } \\
\text { Cerner }\end{array}$ & $\begin{array}{c}\text { Casey and } \\
\text { Medical Record }\end{array}$ & \multicolumn{2}{|c|}{ Every MONDAY } & & & & & \\
\hline $\begin{array}{l}\text { Completing infection surveillance } \\
\text { form }\end{array}$ & $\begin{array}{l}\text { PM/Quality } \\
\text { Director }\end{array}$ & $3 / 8 / 21$ & $4 / 30 / 21$ & & & & & \\
\hline $\begin{array}{l}\text { Logging the infection surveillance } \\
\text { forms }\end{array}$ & $\begin{array}{l}\mathrm{PM} / \text { Quality } \\
\text { Director }\end{array}$ & \multicolumn{2}{|c|}{ Every FRIDAY } & & & & & \\
\hline $\begin{array}{l}\text { Analyzing trends in the infection } \\
\text { surveillance logs }\end{array}$ & $\begin{array}{l}\text { PM/Quality } \\
\text { Director }\end{array}$ & \multicolumn{2}{|c|}{ Every MONDAY } & & & & & \\
\hline Task & $\begin{array}{l}\text { Responsible } \\
\text { Party }\end{array}$ & Start & End & $\begin{array}{c}\text { January } \\
2021\end{array}$ & $\begin{array}{l}\text { February } \\
2021\end{array}$ & $\begin{array}{c}\text { March } \\
2021\end{array}$ & $\begin{array}{l}\text { April } \\
2021\end{array}$ & $\begin{array}{l}\text { May } \\
2021\end{array}$ \\
\hline Computing CLABSI rate & $\begin{array}{l}\text { PM/Quality } \\
\text { Director }\end{array}$ & \multicolumn{2}{|c|}{ Every MONDAY } & & & & & \\
\hline Data synthesis and analysis & $\begin{array}{l}\text { PM/Quality } \\
\text { Director }\end{array}$ & $5 / 3 / 21$ & $5 / 7 / 21$ & & & & & \\
\hline $\begin{array}{l}\text { Polishing final presentation of data } \\
\text { analysis }\end{array}$ & PM & $5 / 10 / 21$ & $5 / 14 / 21$ & & & & & \\
\hline Presenting results to stakeholders & PM & $5 / 18 / 21$ & $5 / 18 / 21$ & & & & & \\
\hline
\end{tabular}




\section{APPENDIX K}

Table 10

\begin{tabular}{|c|c|}
\hline EXPENSES & \\
\hline $\begin{array}{l}\text { Education Supplies (Printing } \\
\text { handouts for staff nurses and nurse } \\
\text { leaders) }\end{array}$ & $\$ 20$ \\
\hline Statistician & $\$ 50$ \\
\hline Others & \\
\hline Total Expenses & $\$ 70$ \\
\hline
\end{tabular}

APPENDIX L

\section{CLABSI Rate Formula}

Number of CLABSI

CLABSI Rate $=$ X 1000

Central Venous Catheter Days 
APPENDIX M 


\section{Image 1}

Evidence Based Practice Review Council Approval
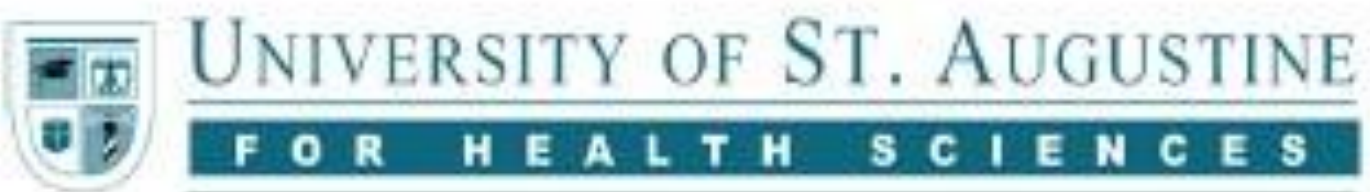

\section{F O R H E A L T H S C I E N C E S}

Doctor of Nursing Practice Program

Evidence-Based Practice Review Council

1 University Blvd.

St. Angustine, FL 32086

March 4, 2021

Dear Caselyn Lok,

Your proposal titled "Reduction of CLABSI in Fountain Valley Regional Hospital and Medical Center's Telemetry Unit patients through limiting central line blood draw" has been reviewed by the University of St. Augustine for Health Sciences Doctor of Nursing Practice Evidence-Based Practice Review Council (EPRC) and determined to not meet the requirements for resenrch as defined in the Federal Register.

Your proposal reflects an evidence-based practice change project and is approved. The proposal must be implemented as subanitted (changes are not permitted). You maxy proceed to obtain approvals from the facility where the project will be implemented as socn as the primary course faculty member has reviewed and approved all fixcility application materials. Inplementation may not begin until you have submitted the EPRC approval letter and the facility approval letter to NUR7802 and are notified in writing by practicum course ficulty that you may implement the project.

Questions regarding the USAHS approval process should be addressed to Dr. Douglas Tumer at DTumer ausaedh, Questions regarding the facility approval process should be adtressed to course ficulty.

Sincerely.

Douglas Turuet

Douglas M Tumer, PhD, DNP, RN, CNE, NE-BC, NEA-BC

\section{APPENDIX N}


Image 2

Fountain Valley's Internal Review Board Approval 


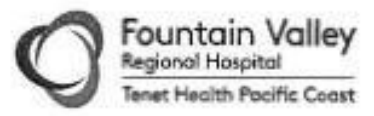

Name of Organization: Fountain Valley Regional Hospital

Street Address: 17100 Euclid St

Fountain Valley, CA 92708

Date: March 04, 2021

The purpose of this letter is to grant Caselyn Lok a student of Universily of St. Augustine for Health Sciences permission to implement an evidence- based practice change, quality improvement, or innovation project at Fountain Valley Regional Hospital.

The Project title: Reduction of CLABSL in Telemetry Unit patients through limiting Central $\underline{\text { Line Blood Draw }}$

Briefly describe the project:

The project will recommend the limiting of central line blood draws by the nurses through strategic interventions. There will be limited blood draws from CVC for eight weeks with rare exceptions such as plwsician orders, emergent draw during cedes or life-threatening events. poor veins of the patient. patient refusal of neripheral draws, and nurses' forgetting the new process. A diagram will be used as a guide in managing blood draws in the telemetry unit. The project will compare the CLABSI rates before and after the implementation of the project within eight weeks.

As the CNO at Fountain Valley Regional Hospital, authorized to act on behalf of Fountain Valley Regional Hospital on student matters, I do hereby grant permission for Caselyn Lok to complete the above stated project at Fountain Valley Regional Hospital.

Signature: Una 4 Denn

Printed Name: EDUA R Dunn

Date: $03 / 08 / 21$

Titles \& Credentials

Phone number: Email address: 


\section{APPENDIX O}

Table 11

CLABSI Rate Computation Table

\begin{tabular}{|c|c|c|c|c|c|}
\hline \multicolumn{6}{|c|}{ CENTRAL VENOUS CATHETER-BLOODSTREAM INFECTION RATES } \\
\hline Month & JANUARY & FEBRUARY & MARCH & APRIL & MAY \\
\hline $\begin{array}{c}\text { Number of } \\
\text { CLABSI }\end{array}$ & 1 & 0 & 0 & 0 & 1 \\
\hline Device Days & 126 & 82 & 112 & 145 & 77 \\
\hline Infection Rate & $7.9 \%$ & $0 \%$ & $0 \%$ & $0 \%$ & $13 \%$ \\
\hline $\begin{array}{c}\text { Average Daily } \\
\text { Census }\end{array}$ & 49 & 37 & 36 & 32 & 35 \\
\hline
\end{tabular}




\begin{tabular}{|c|c|c|c|c|}
\hline Met Desired & No & Yes & Yes & Yes \\
National Infection & & & & \\
Rate Average & & & & \\
\hline
\end{tabular}

* National Infection Rate Average $\leq 5.94 \%$ 